\title{
超音速高等練習機の油圧操縌リグ試験 \\ On the Flight Controls and Hydraulic Systems \\ Rig Test of an Advanced Supersonic Trainer
}

\author{
柴田知治** \\ Tomoharu SiBATA
}

\section{1.はじめに}

琴代の高速機では，舵面に加わる空気力の増大等か ら操緃舵面の油圧作動が不可避であるばかりでなく， 安定操緃性面加らの要求も複雑高度となり, 機械的電 気的に総合化された操縱装置が必要である。また舵面 や降着装置の作動だけでなく, 油王の高出力, 速応性を 利用した油圧作動装置はますます増加し，いわゆる機 構システムの複雑さが大いに増加して来た. このため 各サブ・システムの静的動的機能, 操緥士を含めた機体 全体システムとの適合性，さらには故障時の安全性な どを設計段階で適搉に判断することは，従来から行な われている機器単体の機能試験や，紙上の検討だけで は極めて困難な状況である.すなおち, 他の機体で使 用実績のある部品, あるいはシステムの一部を寄せ集 めて新しいシステムを組み上げても, 機器間の相互干 渉などから生ずる作動不良はなかなか予測し難く、ま た初期故障による飛行安全への影䈉む実物を動かして みない之把握できないものである，とのため，機体開 発と平行して実機をシミュレートしたリグ試験を行な い, 問題点の把握並びに対策の実機への反映, 最適機 器の選定, さらに安全性耐久性の確認などを早期に実 施し，組み立てお上び飛行試験を迅速加つ安全に行な うことが，日程的にす費用的にも効果があるとする考 えが一般化して来た. 油圧, 操縦の各 MIL-SPEC (MIL-H-5440，MIL-F-9490) にリグ試験の実施が規

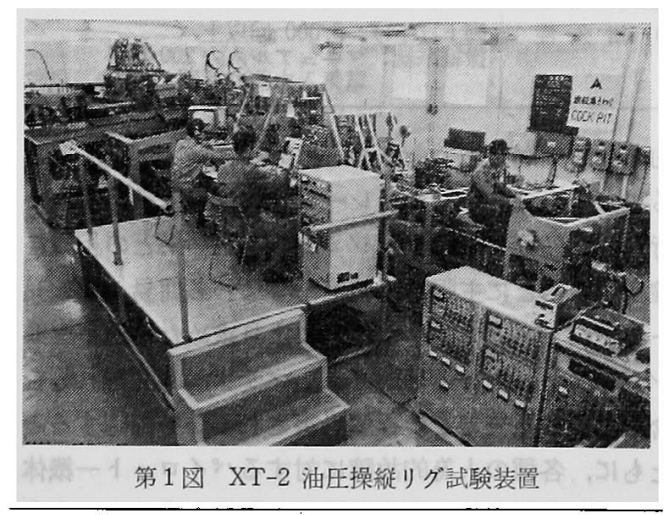

* 昭和 47 年 9 月 7 日原稿受理

** 三菱重工業株式会社名古屋航空機製作所
定されており，PS-1，XC-1 の開発時にもこの種の試 験が行なわれたが，XT-2 の油圧操縦リグ試験は次の 点に特徽があると言える.

1）操絽装置，降着装置，機関砲駆動装冝などは， 同一油圧源で作動し相互に関連するとと，および同一 の架台，供試体，計測装置を共用することにより，費 用的に香有利であるととから，油圧で作動するすへてて の系統を一つの架台に組み込み同時に試験を実施し た.

2）操縦装置の適性を確認するためパイロット・シ ミュレーションを十分に行なうととあに，各種故障状 態, 特殊状況を想定した試験を行ない，安全性の確認 を行なった。

なお本リグ試験は基本設計開始とともに諸準備を始 め, 初飛行の約 1 年 4 か月前に試験を開始し，引き続 き系統耐久試験を実施した。

\section{2. 試験装置}

試験装置は第 2 図に示すように，供試体，架台，負 荷装置, 計測装置, 動力源などで構成されている.

1）供試体 装備品は，概ね本機と同一仕様のあの を使用したが，試験を早く開始する必要から最終仕様 末確定のままに先行して購入し，また費用軽減のため 極力他の試験で使用する供試体と共用するょう心斯け た.リンク類も同様に，初期には機構上必要な幾何学 的寸度のみを一致させた簡略なあのを用いた結果，本 機との相違が問題解決を幾分複雅にはしたが，大きな 障害には至らなかった。なお最終的には本機と同一口 ットで生産された部品に交換し確認試験を実施してい る.

2）架台 架台は主として鋼篮溶接構造であるが， 舵面サーボ取り付け部, 主脚取り付け部, 前脚室など 機器取り付け部の強度剛性が機能に大きく影響する部 分は本機と同一の構造とし，その他の部品は架台に直 接取り付け剛性的シミュレートを考盧していない.

3）負荷装置 舵面負荷は第 2 図に示すようなト一 ション・バーと位置制御油圧サーボを組み合わせた空 気力相当バ亦負荷および舵面相当の慣性負荷とからな り, 飛行状態に応じて連続的に任意の負荷を供試体に 


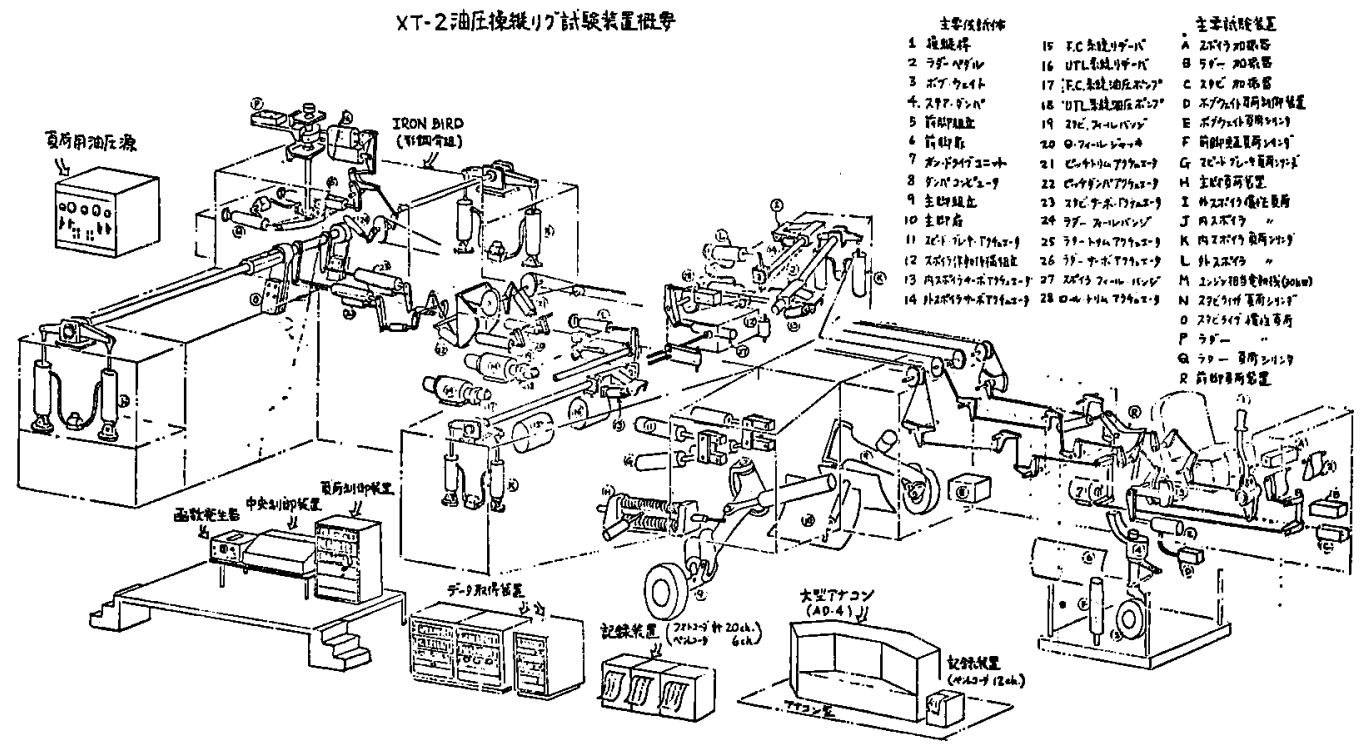

第 2 図 XT-2 油正操縦リグ試験概要

与えることができる. 主脚, 前脚, スピード・ブレー キ等は負荷特性が比較的一定しているため，油王シリ ンダとリンクを組み合わせた単純な非線形バネを用い た. またパイロット・シミュレーション時操維桿に $g^{-}$ フィールを与えるためボブ・ウェート相当の $g$ ウィー ル・サーボを設けた。

4) シミュレータ装置 機体の運動はアナログ・コ ンピュータで計算し主要なパラメータを記録するほ か, 操縦席の模擬計器板に表示した。操綐席にはこの ほ加簡易座席，スイッチ・パネル扰よびスロットル・ レバーを設けた。

5) 計測装置 油圧, 油温, 荷重, 変位等（合計約 200 点）の計湘のため各自的に応じた検出器を取り付 け，データ取得装置 (アンプ等)を介してフォトコー ダまたは XY レコーダに記録した。

6) その他 各種入力波形を得る関数発生器, 入力 加振器, 全システムの作動を集中して行なう中央制御 盤，負荷パターンを制御する目荷制御盤があり，動力 源としては直交流電源，外部油圧源を用いた。

\section{3. 試験内容}

組み立て完了後各系統が正常に作動するまでの組み 立て調整に幾分手間取ったが，正規の試験ではないと の段階でのトラブル・シューティングが当然のととな がら後の本機でのリギング法設定に大いに役立ってい る. 試験項目の概要は第 1 表に示すとおりである．1) 〜3) 項の系統作動試験内容は特に目新しいすのではな いが，备種不具合発生時に本機と異なり，詳細な計測 ならびに十分な解析を行なう時間的余裕があるため，
第 1 表 XT-2 油正操縦リグ試験項目

\begin{tabular}{|c|c|}
\hline 坛験項目 & 内 \\
\hline 1) 㿞 & $\begin{array}{l}\text { 全般機能, 毛力変動, 油温変化, スピード. } \\
\text { プレーキ作動特性, 機関砲動特性 }\end{array}$ \\
\hline 2) 脚系統作動 & $\begin{array}{l}\text { 全般機能，作動時間，非常脚下げ，操向角， } \\
\text { プレーキ特性など. }\end{array}$ \\
\hline 3) 操縦系統作 & 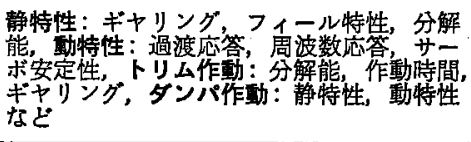 \\
\hline $\begin{array}{l}\text { 4) 油王系統適 } \\
\text { 合性 }\end{array}$ & 王力変動, 油温変化, ポンプ能力など \\
\hline 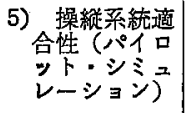 & 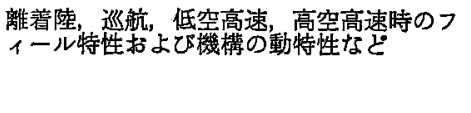 \\
\hline 6）模擬故障 & 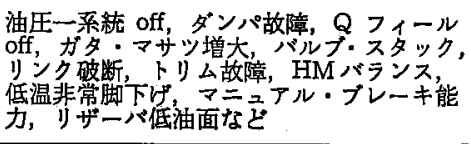 \\
\hline 7) 耐久 性 & 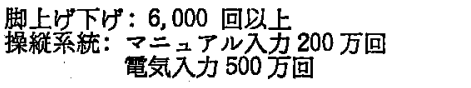 \\
\hline
\end{tabular}

的確な対策が実施できることはリグ試験の利点であ る. パイロット・シミニレーションは基本設計段階で 行なった簡易フライト・シミュレータ結果との相異を 確認するととに主眼を置いた. すなわち簡易シミュレ ータでパラメトリックな検討により求めた最適ギヤリ ング，フィール特性等がガタ，マサッ，時間遅れ等を 含む現実の系統でどの程度阻害されるかを確認すると ともに，各種の人為的故障に対するパイロット一機体 系の現象把握および安全な飛行の限界を求めるとと之 し評価はクーパ・レイティングによって行なった，耐 
久試験では，本機に合わせた潤滑，定期点検，および オーバーホールを実施して，基本的耐久性の確認のほ か，主要機器の MTBF を求めることにより，整備 性，信頼性のデータを得ることを目的としている。

\section{4. まとめ}

以上のリグ試験を通じて次の成果があったと言え る.

1) 本機最終組み立て段階での不具合はほとんどな く，初飛行が予定どおり実施出来た一つの要因之言っ てよい.またその後の飛行試験においても，系統の基 本的不具合は皆無である.

2）シミュレーションにより，パイロットの慣熟, 安全の確保に効果があり，また故障解析にも有用であ った.

3）初期故障の発見, 整備用特殊工具の改良, 適正 点検時間の決定等信頼性, 整備性上の具体的データを 得た.

なお本リグ試験に要する費用はかなりの額であり， 今後の同種試験実施に際しては,リグ試験に期待でき る成果（日程, 改修費用，安全性等）を明確にし，費 用効果の面加らも最適試験規模, 試験項目, 試験時期, 実機シミュレートの程度等をさらに検討する必要があ ろう.

\section{質議討論}

砂川惠(東大宇宙研)：機体剛性と架台のそれが著し く異なる個所のシミュレーションにおける対策はどう 加.

著者: 舵面サーボは機体取り付け部の剛性が作動の 安定性に大きく影響するため前述の如く取り付け部を 実機之同一構造にする必要がある。操䋛系統の一般部 分では，架台の剛性は無限大と考えて最適入出力特性 を決定した後, 本機においてアーム・レショ可変機構
を設けて架台との剛性差（数％）に起因する特性変化 を逃げた。な拉主翼の外部荷重による変形の影響（主 翼の変形によるフラップ・アクチュエータ荷重の增大 など）をシミュレートすることは困難であるため，フ ラップ系統は 01 号機で主翼変形を与えて作動試験を 行なった.

砂川惠: 機体剛性, 操縦系統の剛性およびレスポン 又特性等に機体の運動等を含めて体系的かつ総合的に 地上ですべて検討するリグ試験について，罗来の展望 ああわせてどのように考えているか。

著者：機体系統の剛性だけでなく環境条件も含め て，すへてて地上で検討し尽すことは費用効果的に特策 とは思われない. パイロット・シミュレーションは， 固定座席型シミュレーシータでは自から限界があり， 汎用のムービング・コクピットで十分なパラメトリッ ク・スタディを行ない,リグ試験は，計算モデルと実 物との差の確認装置と考えるのが妥当と思う。また系 統の動特性む現象の解析的把握が，さらに進めば一部 はコンピュータ・シミュレーションに移行するである j.

竹内和之(航技研)：このリグ試験を行なうことによ って発見できた耐久性以外の問題点は何か.

著者: 細部には種々雑多な問題が発見され，その都 度対策の手を打ったが、リグ武験の効果の例として は,

1）多数の計測点と精密な記録装置により，従来比 較的経験で処理していた油圧システムの現象を，かな り解析的に把握できるようになった。

2）現実的な問題としては，舵面サーボ，トリム機 構の応答時間の決定が挙げられる.

3）また操作ミス等で生じた偶発的不具合をきっか けとして，潜在的な事故発生要因をいろいろとつぶす ととができた。 